\title{
Employment Relations, Service Quality and Professionalism within the Nigerian Public Service
}

\author{
Christiana Kappo-Abidemi*1, Chux Gervase Iwu², Charles O.K. Allen-Ile ${ }^{3}$ \\ ${ }^{1}$ University of Mpumalanga, South Africa \\ ${ }^{2}$ Cape Peninsula University of Technology, South Africa \\ ${ }^{3}$ University of the Western Cape, South Africa \\ *C.Kappo-Abidemi@ump.ac.za, iwuc@cput.ac.za, callenile@uwc.ac.za
}

\begin{abstract}
This paper was written with the following in mind: (1) to determine the effect of employee wellness on public servants' professionalism, and (2) to establish the relationship between trade union activities and employee professionalism. Within organisations, employment relations are established to facilitate an interactive working relationship between an employer and an employee as well as determine how labour and social security law provisions addressed to employees are applied. We reviewed pertinent literature that guides employment relations and adopted the mixed methods to enable a rigorous study that will offer profound insight into the employment relations climate in Nigeria and how it affects professionalism. Subjects were drawn from the database of a public funded training provider, whichcaters exclusively for senior public servants. The data are presented in a graphical and narrative form owing to our use of themes in analysing the focus group interviews. Some interesting and at the same time confusing revelations emerge from this study. The distinct difference in the responses holds implications for research and practice. A future study that can clarify this confusion may start by identifying champions (trade unionists, managers at the coalface with unions and other employers) and then engaging them through indepth interviews to understand the real conditions which public servants are exposed. On a practical side, as confusing as the responses seem, they provide a serious opportunity for enhanced studies on Nigeria's public service constitution. We make this call against the backdrop of what some social scientists have termed intense structural decay in the Nigerian public service.
\end{abstract}

Keywords: Public service, Servqual, Professionalism, Employment relations, Trade unions

\section{Introduction}

Employment relations is an essential part of human resource management that oversees the relationship and interaction between employees and employers by ensuring that the two parties operate within the legislative provisions of the state. According to ILO (2006), employment relations signifies the formal coming together of an employer and an employee and generally defines the "reciprocal rights and obligations ... created between the employee and the employer" (Pg. 3). Thus, employment relations are established to create an interactive working relationship between an employer and an employee. It is the "key point of reference for determining the nature and extent of employers' rights and obligations towards their workers" (Pg. 10). It also exists to determine how labour and social security law provisions addressed to employees are applied. Several factors hinder the smooth facilitation of the employment relationship. These factors include collective bargaining, employee wellness and dispute resolution mechanism. If these factors are not managed properly, a negative consequence ensues which affects the overall professional output. Negative consequences of ill-applied employment relations abound. For instance, because of job insecurity, workers may react to their duties and responsibilities with lacklustre attitude, which may compromise their health and safety (Ale, 2008; Idubor and Oisamoje, 2013). An effective human resource management approach is one that looks after each employee's welfare - health and safety, training and development, compensation and so on (Salawu, Hassan and Adefeso, 2010). Employers are thus expected to have a holistic interest in finding and placing employees within the work setting and as well prioritise their welfare.

Therefore, the study examines the relationship between employment relations and public servants' professionalism in the Nigerian public service. The intention is to determine the:

- effect of employee wellness on public servants' professionalism, and

- relationship between trade union activities and employee professionalism.

Public servants are burdened with a different responsibility from that of employees in other employment sectors. Part of their job responsibility is to strive for a balance between their political allegiances and work 
responsibility (Sarmavicius, 2006). This goes to show that the public service is complex because government is both the employer and custodian of the law. Nonetheless, Venter and Levy (2014) reckon that when the state is also playing the role of employer in an employment relationship, the provisions of the legislation it provides also bind it.

The rest of the paper is presented as follows: In the next section, we review pertinent literature that guides employment relations. An important adjunct to our review is the concept of service quality, which we are convinced, is articulated better within the servqual paradigm. Following that is a discussion of the research design. The paper concludes by uncovering some important ramifications.

\section{Theoretical perspectives}

Employment relations is guided by some theories amongst which Pluralist, Marxist, and Unitary theories are most popular. These theories are briefly discussed below to provide some scope to this study. In addition, service quality with specific reference to the servqual model is briefly discussed in relation to professionalism.

Pluralist theory: This theory is characterised by its style of involving employees in decision-making and bargaining process through their unions. Pluralist theory is considered to be the best of all the three theories (Budd, Gomez, and Meltz, 2004; Venter and Levy, 2014) that we have adopted in this study. The terms and conditions of employment are determined through collective bargaining, conflict resolution and negotiation between parties' representatives in this approach (Aborisade, 2008). In addition, preference is given to stakeholders such as government, trade unions, employers' organisation, consumer associations and professional bodies on employment related issues (Budd et al., 2004).

Marxist theory: Karl Marx advocates that employees should be allowed to take ownership of their productand jointly own resources. Thus, his doctrine discourages capitalism in all forms. Hence, workers should not be disconnected from their final product by earning a salary or wage (Okey and Onyishi, 2011). Employees through their unions should be involved in economic, political and decision-making of the state (Venter and Levy, 2014). The continuous rift between employer and employee about ownership of resources creates political and social unrest. Although, the duties and responsibility of the state are not clearly stated in the theory, emphasis is on the state promoting socialist ideologies (Okey and Onyishi, 2011).

Unitary theory: This approach is about the power and influence an employer seems to have over employees. Due to the power and influence possessed by the employer, wages and conditions of service are unilaterally determined without consulting the other party. This approach is characterised by industrial unrests and conflicts that disrupt productivity (Nel, Kirsten, Swanepoel, Erasmus and Jordaan, 2016). Issues such as job insecurity, unclear communication, remuneration and poor working conditions, which in turn may thwart employee and employer output especially if industrial relations are poorly practised (Venter and Levy, 2014), can cause industrial conflicts.

Service quality (Servqual): This concept of servqual gives preference to customer's perception of service and rates the employee or organisation according to how the recipients of their service is perceived (Chingang, Lukong and Isberg, 2010). Customers' perception of service is measured based on their experience, expectation, word of mouth and communication. Essentially, servqual measures the difference between customer's expectation and perception. Although Untaru, Ispas and Dan (2015) acknowledge that quality service can only be contextually described based, certain generic standards are used to measure service delivery. These include tangibles, reliability, responsiveness empathy and assurance (Ilyas, Nasir, Malik, Munir and Sajid, 2013). There have also been replicas of the servqual model such as Service Compact or Servicom, which was introduced in Nigeria's public service in order to reorient professional customer service. Agboola (2016) and Oyedele (2015) however contend that the failure of the system to improve service delivery is a function of the discrepancy between customer expectations and perceptions of service. This somewhat aligns with Shahin's (2004) argument that whatever quality service model is in place must unravel both the customer's service expectations and perceptions and an employee's perceptions of 
management's wellness programmes. We are therefore convinced that the servqual model makes an important contribution in the discussion of professionalism within the Nigerian public service.

The state of Nigeria's public service: Onyejeli (2011) reckons that Nigerian public servants are among the least paid in Africa. With rising inflation and unemployment, the conditions of service are equally deplorable. It is not uncommon to hear that wages are discretionally decided by the government without any form of input or consultation from the workforce, financial experts or other stakeholders. Lack of consultation and consideration has led to various industrial actions. In the event of an industrial action, the Nigerian public is subjected to school closure, often including sporadic violent protests. According to Agba and Ushie (2013), a situation such as this further regress the economy as those who are expected to lead the country are unable to attend school while workers stay away from work. Another common problem within the Nigerian public service is the weak incentive system which is mostly seen as hampering productivity promoting corruptive practices and generally destabilising ministries, departments and agencies (MDAs) (Akinwale, 2011). Okey and Onyishi (2010) refer to an 'alien job grading system' which was introduced within the public service without due consideration for public servants working conditions, payment and promotion system. Because of the job grading system there has been growing resentment in the Nigerian public service. Despite the unhappiness arising from the grading system, public servants complain about outdated and dysfunctional apparatus they have to work with (Anyim, Chidi and Ogunyomi, 2012).

Notwithstanding collective measures put in place to address workplace-related issues, employee wellness is also given little or no consideration. This is evidence that the prevailing discontent within the Nigerian public service results from a lack of collective bargaining. Ordinarily, collective bargaining is expected to promote professional standards, grievance handling, mutual interests and service to the public, the sharing of occupational skills and experience amongst employees and employers instead of the prevailing discontent (Anyim, Ekwoaba, and Shonuga, 2013; Anyim, Osekola and Olusiji, 2011).Collective bargaining is one of the most powerful tools for management and employee representation in order to reach mutual agreements on employment related issues right from recruitment to retirement (Paul, Michael and Chukwurah, 2013). When such a tool lacks in the workplace, there is possible tendency for repeated industrial action. A report by Sanes and Schmitt (2014) shows that, administration of collective bargaining, wage negotiation and industrial action seem to be very complex and ambiguous in some states in USA. However, industrial relations thrive where human resource management practices are functional and produce a better response to collective bargaining for all categories of employees (Brewster, 1995; Silva, n.d). Huselid (1995) adds that the involvement of employees in decision-making can increase the knowledge, skill and ability of current and future employees of an organisation, improve motivation, reduce redundancy and enhance retention of quality employees.

Professionalism is described within job requirements and ethics. Hence, public servants' professionalism is determined based on public service job requirements and the professional ethics of the specific job (Pope, 2000; Ssonko, 2010; UNDESA, 2000). Having a public service with all qualities of professionalism will ensure that interests are prioritised, service delivery is efficient and effective and political affiliation will not be given preference at the expenses of career obligations. On-going learning will also be part of the organisational culture to enhance the organisational ethics and standard (Gebrekidan, 2011). In order to achieve these professional qualities in the public service, government should provide an enabling environment to facilitate constant interaction amongst all stakeholders.

\section{Methodology}

The mixed method of research was deployed to facilitate a rigorous study that would offer profound insight into the employment relations climate in Nigeria and how it affects professionalism. According to Bless, Higson-Smith and Sithole (2013), quantitative research is aimed to give explanation, identify a relationship between variables, expressing 'social law' and generalisation of findings, while qualitative research is aimed to understand a phenomenon in its natural setting and generalise those findings to other similar situations. Hence, the deployment of the mixed method is justified for its capacity to support a holistic inquiry that unpacks a phenomenon. Subjects were drawn from the database of Administrative Staff College of Nigeria (ASCON). ASCON is a public funded training provider, which caters exclusively for senior public servants 
(normally from grades 7 to 17). The subjects were randomly selected from the cohort of 2013 trainees. Brynard, Hanekom and Brynard (2015) describe random sampling as when every subject within the unit of analysis has the same chance of taking part in the study. We considered senior public servants appropriate for the study because of their privileged position to offer better insight into employment relations climate of the Nigerian public service. We distributed more than one thousand two hundred questionnaires but made use of four hundred and seventy-nine (479) of them because they were properly filled out. The data were collected over six months including focus group discussions. With respect to focus group discussions, three groups consisting of 10-12 people were formed. The quantitative part of the questionnaire is descriptive in nature while the relationship between employment relations variables and professionalism is also established. Creswell, Ebersohn, Eloff, Ferreieira, Ivankova, Jansen, Nieuwenhuis, Pietersen and Plano Clark (2016) mention that quantitative research tests theories about reality, examine the possible cause and effect, and measures to gather data to test hypotheses or answers to research questions. The questionnaire used for quantitative data collection was close-ended, with the options to agree, disagree and or uncertain.

\section{Data Analysis and Results}

The data are presented in a graphical and narrative form. The focus group discussion is analysed thematically, while the correlative group responses are narrated under each group. Pertinent employment relations variables such as trade unionism, collective bargaining, and workplace participation and employee welfare were examined together. 'Employment relations' is described as the legislative framework that guides the relationship between employees and employers in the workplace within a country. The study sought to examine the relationship between the Nigerian Public Service (employer) and its employees' professionalism. Employment relations consists of trade unionism, collective bargaining, employee wellness and disciplinary and grievance procedures. These constituted the items in the data collection instrument. The Cronbach's Alpha used to test the reliability of the instrument achieved $\mathbf{0 . 7 4 5}$ thus proving that the results were reliable. To determine the validity of all the questions that address employment relations and their effect on professionalism, factor correlation was adopted. The average outcome of all responses was used to evaluate their relationship with one another. The factor correlation was therefore used to determine the level of significance of the relationship as well as the coefficient of determination.

Table 1: Factor correlations for all variables

\begin{tabular}{llcc}
\hline & Professionalism & $\begin{array}{c}\text { Employment relation } \\
\text { management }\end{array}$ \\
\hline Professionalism & Pearson Correlation & 1 & $.515^{* *}$ \\
& p-value (2-tailed) & & .000 \\
Employment & $\mathrm{N}$ & 477 & 469 \\
relations & Pearson Correlation & $.515^{* *}$ & 1 \\
management & $\mathrm{p}$-value (2-tailed) & .000 & .000 \\
\hline
\end{tabular}

p-value is significant at $\geq 0.05$

Pearson correlation range from 0-1 (The closer to 1 the higher the $R$ )

There is a significant relationship between employment relations and professionalism as shown in Table 1 above. The graphical illustration of the research finding is shown and analysed below. 
Figure 1: Graphical illustration of participant's responses to employee relations in Nigerian public service

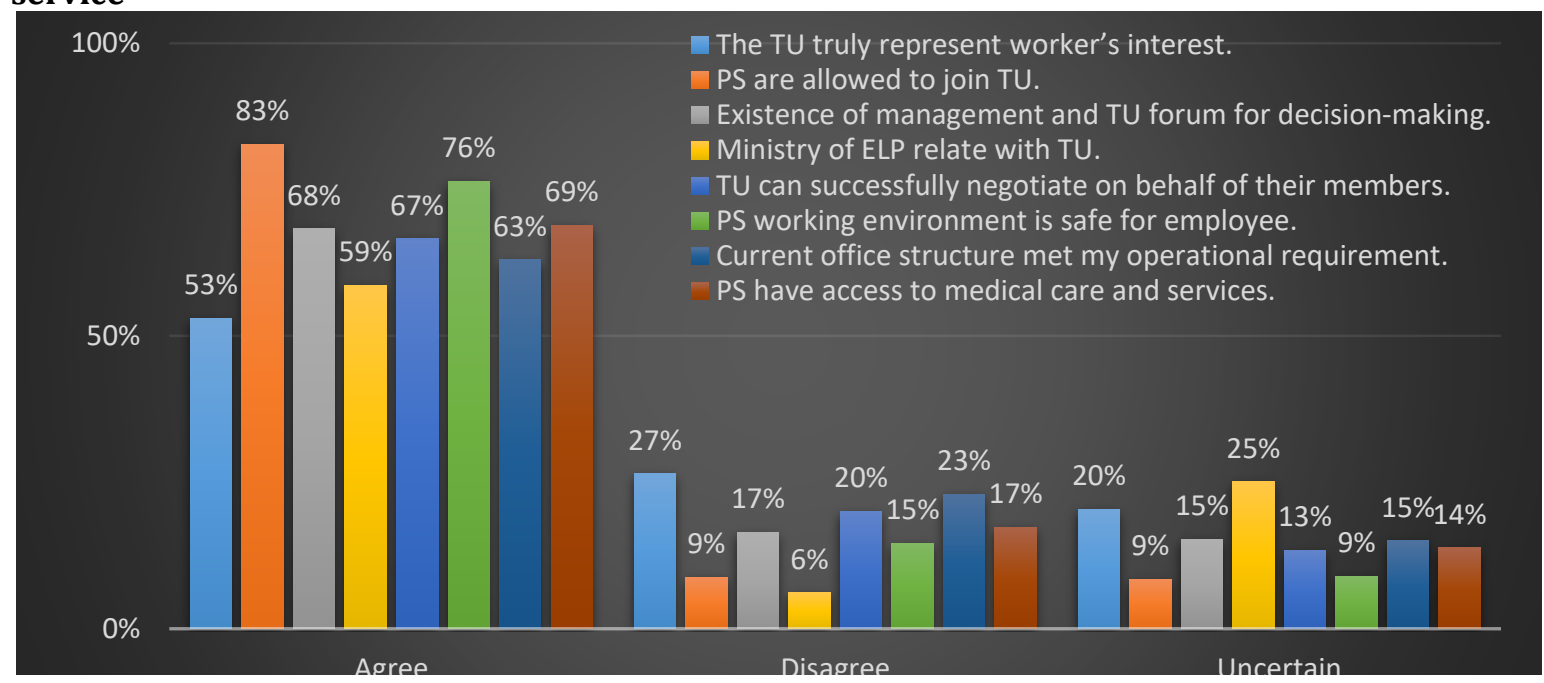

*TU = Trade union; PS=Public service/servants

The above graphic illustration depicts the existence of trade union and its operation. It is shown in the Figure 1 that $53 \%$ of the participants agreed that their interests are truly represented by their trade union, $27 \%$ disagreed and $20 \%$ were uncertain. The figure also shows participants' responses to how civil service policy provide employees the freedom to join TU's. Here, $83 \%$ of the participants' agreed that the civil service policy offers employee's freedom to join trade unions, 9\% disagreed and $8 \%$ were unsure. The figure above also shows how respondents reacted to collective bargaining related issues. Respondents answered to how management interacts with trade union officials: $68 \%$ of the respondents agreed that there is a meeting point between management and union officials, $17 \%$ disagreed and 15\% were not sure. The relationship between the Ministry of Employment, Labour and Productivity (ELP) and trade unions is also depicted in the figure; $59 \%$ agreed that the ministry and trade union have a good working relationship, $16 \%$ disagreed and $25 \%$ were uncertain. Likewise, the union negotiation ability was examined and $67 \%$ of the participant agreed that their union have negotiation skills, while $20 \%$ disagreed and $13 \%$ were not sure.

The well-being of employees in the ministry is also depicted in the figure above. The figure shows that $76 \%$ of the respondents agreed that their ministry's work environment is safe, $15 \%$ disagreed and $9 \%$ were uncertain. The figure also explains responses to operational requirements of public servants: $63 \%$ of the participants' responded that the office structure was in line with their operational requirements, $23 \%$ disagreed while $15 \%$ were uncertain. With respect to access to medical care and facilities, $69 \%$ agreed that public servants have access to medical facilities, while $17 \%$ disagreed and $14 \%$ were not sure. The results depicted above indicate a positive feeling amongst the participants regarding their trade union federations' activities, the collective bargaining tools and employee wellness programmes. This result sharply contrasts with those of Anyim, Elegbede and Gbajumo-Sherif (2011) as well as Ibietan (2013) who maintain that what most workers regard as collective bargaining is mostly a fiat expression of government orders while the trade unions are relegated to the background. Below, the focus group interview is discussed in the form of a summary.

\section{Focus Group Interviews}

Question 1: How do employment processes in the public service affect employees' attitudes to work?

Group 1: The recruitment process in the public service is different from state to state. Basically, in some states, recruitment exercise takes place only when there is a vacancy. However, priority is not placed on the discipline or credentials of the person that will occupy the position rather someone with "connection" to a higher authority or to a popular political figure. Even though the process may be properly constituted, one finds massive political interference because in the end a noticeable link is made between the new hire and a 
popular political figure. Irrespective of the qualification and professional measures put in place, once the candidate is related to any political office holder, due process becomes irrelevant. Lack of due process jeopardises any form of responsibility from an employee since the position was not earned on merit. Such employees know that they can always cry to the godfather that influenced the employment in the first place whenever things go wrong and get away with the possible consequences. Hence, the employee will not show any sign of commitment to the duties and responsibilities at work. In this case, the new hire will very likely not take instructions or defer to his superiors. As Chukwuemeka (2012) points out, god-fatherism has delegitimized public service recruitment process and as a result, negatively influenced its outcomes.

Group 2: All intending and existing employees are expected to be provided with equal opportunity but some people seem to be getting preferential treatment above others. For example, intending employees that are connected to "people in power" in Nigeria seem to get the job, with little or no reference to their qualifications. Such employees are always egotistical and irresponsible with their duties. Those who are subjected to thorough recruitment procedure may have less chance of getting the job if they have no "connection". Managers of departments including HR units are often side-lined during recruitment. Similar situation is also applicable to promotion system; the set standard is mostly ignored while power play takes precedence. The public servants are not ignorant of this power play, hence, majority ignore their primary responsibility of quality professional service delivery in order to curry favour. The common perception therefore is that those who join the public service are there either to use the service as a platform for their next employment or to partake in corruptive practices.

Group 3: Undeserved promotion is rife within the Nigerian public service leading to recalcitrant work attitudes and low morale among workers. Those who are randomly promoted miss important on-boarding programmes such as coaching and mentoring, hence, a big vacuum is created in the employment chain. Application of the quota system in government recruitment and promotion structure has discouraged consistent application of merit. Some geographical zones have more educated persons than others yet the policy insists on equal representation at all levels of employment irrespective of qualification and skills possessed. A fresh graduate from a particular geographical location can be on a level far above his contemporary or an older employee from another geographical location with similar qualification and years of experience. There is possibility that the fresh graduate with no experience that is placed on higher level due to his state of origin may become arrogant and think he or she is better than others are. Apart from the quota system, another known factor that influences employment process in the Nigerian public service is "god-fatherism". This defies all forms of norms in the recruitment process and irrespective of qualifications, skills or experience, the godfather candidate will always emerge the preferred candidate. A god-father candidate is only answerable to the god-father with no regard for any employment policy or norm.

Question 2: What is the role of Nigerian Civil Service Union in the relationship between the Civil Service Commission and its employees?

Group 1: Apparently, all participants in this group are paid-up members of Nigerian Civil Service Union. They all mentioned that the union is very active when it comes to wage negotiation and seems not to be doing well in the area of condition of service. In addition, the union is seen to be the conduit for government and employees.

Group 2: Most participants from this group mentioned that the union is only negotiated and mediate in issues that affect all members but not involved when individual members are in trouble with the employer. However, there is a contrary opinion that in most cases unions are not aware of the individual problems and as a result are not able to mediate, that the union will support their member in any case as long as it is not criminally related.

Group 3: The public service has roughly eight industrial unions, which ought to serve as worker representatives notwithstanding unions' involvement in politics. It is not uncommon to find worker union leaders joining or fronting for political parties once they are elected into office. This gives rise to conflict of interest as some of the parties are in contention with the objectives of the workforce. Therefore, they find it 
difficult to differentiate the union agenda from the management interest, hence, in most cases management is favoured at the expense of workers.

Question 3: Is there any avenue for the employees (unions/union federation) and employer (state) to meet and discuss work-related issues?

Group 1: Yes.

Group 2: The Labour Consultative Forum provides such avenue.

Group 3: This group's opinion is similar to the previous two groups.

Discussion: Contrary to Adeniji's (2015) and Uzoh's (2015), description of a poorly established collective bargaining system in the Nigerian public service, the research participants seem not to see anything wrong with employment relations climate of NPS. Some of the participants in this study indicated that ER policies are adhered to. This leaves one to wonder why there is so much negativity associated with the NPS. The best one can make of the results here is that Nigerian public servants squabble over selfish interests because of the diminishing quality of life in the country. Therefore, while there may be systems in place to deal with ER issues as reported by the participants, attention may not necessarily focus on the functionality of the systems. Having said this, we also note some misgivings regarding the findings. Firstly, the subjects were senior public servants who may have little or no issues outside of wage/salary considerations. Secondly, focused group discussions have noted that senior appointments and promotions are made based on political loyalty. Therefore, if the political party in power influences appointments, we suspect that the responses may have been coloured to fit the interest of the superiors.

Other employment related issues such as job security and occupational health and safety were discussed as they affect employee's attitude to work. For instance, there are government establishments that are responsible for developing the skills of health inspectors, medical and safety officers and specifically how to handle work related health and safety issues as well as legal guidance (Ale, 2008: Idubor and Oisamoje, 2013, Kalejaiye, 2013 and Employment Compensation Acts, 2010). Despite the provisions of the ministries and legal recourse, any injury or illness that does not happen right in the workplace is not taken care of in the legislative framework. Policies such as wage dispute and compensation that are put in place are not well implemented to serve its purpose.

Lastly, Okaka and Eriaguna (2011) reckon that most people hired by the Ministry of Employment, Labour and Productivity to implement these policies are not qualified or possess the needed skill to effectively carry out the job. This corroborates responses that unions do not give support to individual employees on personal employment related issues. Another problematic issue in the Nigerian public service is that there is no proper record of workplace injury; hence, affected employees are not compensated. In addition, wage dispute is an ongoing issue within Nigeria public service because they are never adequately resolved; instead, quick temporary solutions are usually sought. Every employment relations problem deserves holistic attention from the human resource management of all MDAs (Salawu, Hassan, and Adefeso, 2010). HR is responsible for job design, job description and job grading and wage and conditions of service; it should be allowed to conduct its affairs accordingly. This will ensure that the right people with the right skills are employed and adequately compensated, instead of unprofessional and incompetent employees who only care about their wages, even when they cannot do the job.

\section{Conclusion and Ramifications}

Some interesting and at the same time confusing revelations have emerged from this study. Firstly, the participants have hailed their labour unions for effectively looking after them during crisis. This leaves us wondering whether the unions are not complicit. Considering the focus group narratives of god-fatherism, laxity, and so on, one would expect the labour unions to stand against these instead of simply standing by their members when things go wrong. Does this mean that the unions' role is now limited to providing support to their members in times of trouble? Can one say that because the unions perceive the system as corrupt, and are unable to clean it up, they should rather come to the defence of their members who should not be blamed because the system is already messy? Secondly, the Figure 1shows positive work relations, access to medical service, and safe workplaces. This is surprising again, in relation to what we obtained 
during focus group discussions. This magnifies the difference between responses from the questionnaire and the interviews. The results obtained through quantitative means is not consistent with literature (see Onyejeli, 2011; Kalejaiye, 2013; and Okey and Onyishi, 2011) that portrays the Nigerian public service to be lacking conducive work environment. The distinct difference in the responses holds implications for research and practice. A future study that can clarify this confusion may start by identifying champions (trade unionists, managers at the coalface with unions and other employers) and then engaging them through indepth interviews to understand the real conditions which public servants are exposed.

Our choice of senior public servants as participants may have also affected the outcome of this study. Therefore, a future study may consider lower cadre staff's opinions on a range of issues including junior staff wellness. On a practical side, as confusing as the responses seem, they provide a serious opportunity for enhanced studies on Nigeria's public service constitution. This call is made against the backdrop of what some social scientists have termed intense structural decay in the Nigerian public service.In closing, it is necessary, given the findings that the following points are noted: (1) there is a serious misalignment of employment priorities within the Nigerian public service; (2) Nigeria ranks poorly in the global transparency index including the ease of doing business index; (3) countries that fare much better are known to have very strong governance systems and infrastructure; (4)dedicated professionals within public service produce good governance;(5) functional systems are supported by infrastructure. Therefore, to do away with the consistent low rating on both local and international fronts, Nigeria requires a public service that is focused, thorough in its operations and sincere to its people.

\section{References}

Abbott, K. (2006). A Review of Employment Relations Theories and Their Application.Problems and Perspectives in Management, 1, 187-199.

Abbott, K. (2007). Employment Relations: Integrating Industrial Relations and Human Resource Management. Problem and Perspectives in Management, 5(1), 61-71.

Aborisade, F. (2008). Industrial Relations: Ideological Perspective. Delivered at ConferenceOrganised by the World Federation of Trade Unions (WFTC).

Agba, A. M. \& Ushie, E. M. (2013). Wages Differentials and Industrial Disputes in NigerianHospital. Journal of Business and Management, 11(5), 01-12.

Agboola, T. (2016) Service Compact and Service Delivery in Nigeria: An Empirical Study.International Journal of Politics and Good Governance, 11(7.3), 1-26.

Akinwale, A. A. (2011). Labour Reform and Industrial Conflicts Mismanagement in Nigeria.The Sixth IIRA African Regional Congress of Industrial Relations: Emerging Trendsin Employment Relations in Africa: National and International Perspectives. Availableat: http://www.ilo.int/public/english/iira/documents/congresses/regional/lagos2011/5thsession/ses sion5b/regorms-conflict.pdf [Accessed on 19 December 2014].

Ale, A. (2008). Tension in LUTH after Gunman Raped Pregnant Doctor. Available online at:http://www.naijarules.com/xf/index.php?threads/tensions-in-luth-after-gunman-rapedpregnant-doctor.30331 [Accessed 30 May 2013].

Anyim, C. F., Chidi, O. C. \& Ogunyomi, O. P. (2012). Trade Dispute and SettlementMechanisms in Nigeria: A Critical Analysis. Interdisciplinary Journal of Research in Business, 2(2), 01-08.

Anyim, C. F., Elegbede, T. \& Gbajumo-Sheriff, M. A. (2011). Collective Bargaining Dynamics in the Nigerian Public and Private Sectors. Australian Journal of Business and Management Research, 1(5), 63-70.

Anyim, F. C., Ekwoaba, J. O. \& Shonuga, A. 0. (2013). Industrial Unionism and its BargainingCorrelates in Nigeria Industrial Relations System. Journal of Management andStrategy, 4(3), 56-64.

Anyim, F. C., Osekola, I. C. \& Olusiji, O. P. (2011). Collective Bargaining and its Metamorphosis in the Workplace in Nigeria. British Journal of Economics, Finance and Management Sciences,2(1), 63-70.

Armstrong, M. (2006). A Handbook of Human Resource Management Practice. 10th Ed. KOGAN PAGE. London and Philadelphia.

Bless, C., Higson-Smith, C. \& Sithole, S. (2014). Fundamentals of Social Science ResearchMethods. An African perspective. Fifth Edition. Juta \& Company Ltd Cape TownSouth Africa

Brewster, C. (1995). Industrial Relations and Human Resource Management: A SubversiveEuropean Model. Industrielle Beziehungen, 2(4), 395-413. 
Budd, J. W., Gomez, R. \& Meltz, N. M. (2004). Why a Balance is Best: The Pluralist IndustrialRelations Paradigm of Balancing Competing Interests. Prepared for Conference onTheoretical Perspectives on Work and the Employment Relationship. IndustrialRelations Research Association, 2004 Research Volume. Available online at thefollowing website: http://www.researchgate.net/profile/Rafael_Gomez6/publication/30528256_Why_a_balance_is_bes t_the_pluralist_industrial_relations_paradigms_of_balancing_competing_interests/links/00463520a8 e275c333000000.pdf [Accessed 14 May 2015].

Chingang, D. N., Lukong, P. B. \& Isberb, S. (2010). Using the SERVQUAL Model to AssessService Quality and Customer Satisfaction. An Empirical Study of grocery store inUmea. Umea Business School Master thesis. Available online at http://www.diva-portal.org/smash/get/diva2:327600/fulltext01 Assessed on 18 March 2018.

Employee Compensation Act. (2010). Federal Republic of Nigeria Official Gazette. Availableonline at http://www.nsitf.gov.ng/ecs3/ECA\%202010.pdf [Assessed on 19 April 2017].

Grobler, P. A., Warwirch, S., Carrell, M. R., Elbert, N. F. \& Hatfield, R. D. (2011). HumanResource Management in South Africa. Cencage Learning 4th Ed

Idubor, E. \& Oisamoje, M. D. (2013). An Exploration of Health and Safety Management Issuesin Nigeria's Effort to Industrialize. European Scientific Journal, 9(12), 154-169.

Ilyas, A., Nasir, H., Malik, M. R., Munir, S. \& Sajid, A. (2013). Assessing the service qualityof Bank using SERVQUAL model. Interdisciplinary Journal of ContemporaryResearch Business, 4(11), 390-400.

International Labour Conference 95 ${ }^{\text {th }}$ Session. (2006). The employment relationship. ReportV(I). Available on http://www.ilo.org/public/english/standards/relm/ilc/ilc95/pdf/rep-v-1.pdf Assessed on 18th March 2018.

Kalejaiye, O. P. (2013). Occupational Health and Safety: Issues, Challenges and Compensationin Nigeria. Peak Journal of Public Health and Management, 1(2), 16-23.

Martinovic, M., Pavlic, I. \& Tolic, M. S. (2017). Measurement of Local Public ServicesQuality Using SERVQUAL. The Case of Dubrovnik. EkonMisao I PraksaDbk God, XXVI BR.2(593-610).

Musa S. A. (2001). Charter for public service in Africa: Strategic for Implementation inNigeria. African Training and Research Centre in Administration for Development. Available online at the following website: http://unpan1.un.org/intradoc/groups/public/documents/un-dpadm/unpan044624.pdf [Accessed 10 December 2013].

Nel, P. S., Kirsten, M., Swanepoel, B. J., Erasmus, B. J. \& Jordaan, B. (2016). South AfricanEmployment Relations. Theory and Practice ( $8^{\text {th }}$ Edition). Van Schaik Publishers. Pretoria.

Nnonyelu, A. N. (2012). The State and Trade Unions: A Dialectical Framework for Understanding Industrial Relations in Nigeria. Asian Journal of Business and Management Science,2(8), 16-23.

Okaka, E. O. \& Eriaguna, E. (2011). Government Agents in Nigeria's Industrial Relations System. Journal of Research in National Development, 9(1), 187-192.

Okey, M. I. \& Onyishi, A. O. (2011). Global Determinants and Contexts of ContemporaryIndustrial Relationships Policy in Nigeria. Labour Management in Development Journal, 12, 1-22.

Onyejeli, N. (2011). Nigeria Public Policy. The SLOAN Centre Aging \& Work at BostonCollege. Global Policy Brief 18.4 Available online at the following websitewww.bc.edu/content/dam/files/research_sites/agingandwork/pdf/publications/GPB18_Nig eria.pdf [Accessed 13 December 2014].

Osamwonyi, I. O. \& Ugiagbe, E. O. (2013). Harmonious Industrial Relations as a Panacea forAiling Enterprises in Nigeria. Journal of Asian Scientific, 3(3), 229-246.

Oyedele, S. O. (2015). The Nigerian Public Service and Service Delivery Under Civil Rule.Journal of Public Administration, Financial and Law, 7(2).

Paul, S. O., Michael, S. A. \& Chukwurah, D. C. (2013). Trajectory and Dynamics of CollectiveBargaining and Labour Unions in Nigeria Public Sector. International Refereed Research Journal,4(4), 49-57.

Salawu, B., Hassan, A. \& Adefeso, A. (2010). Workers-Government Wage Relations and Unresolved Issue of Income Inequality and Labour Strikes in Nigeria: Suggestion for the Way Forward. Journal of Public Administration and Policy Research, 5(3), 61-67.

Sanes, M. \& Schmitt, J. (2014). Regulation of Public Sector Collective Bargaining in the State. Centre for Economic and Policy Research Washington. Available online at:http://www.cepr.net/documents/state-public-cb-2014-03.pdf [Accessed 2 February 205]. 
Sarmavicius, O. (2006). Presented on Civil Service Recruitment: Why to Change. Seminar on Civil Service Recruitment Procedures Vilnius 21-22 March. SIGMA.

Silva, S. R. n.d. Human Resource Management, Industrial Relations and AchievingManagement Objectives. International Labour Organisation Publication. Available Online at: http://www.ilo.org/public/english/dialogue/actemp/downloads/publications/srshrm.pdf [Accessed 5 February 2015].

Ssonko D. K. W. 2010. Ethics, Accountability, Transparency, Integrity, and Professionalismin the Public Service: A Case Study of Uganda. Capacity Building Workshop for Public Sector Human Resource Managers in Africa on Strengthening Human Resource Capacities for the Achievement of the Millennium Development Goals and Africa's Development Cotonou, Republic of Benin.

Untaru, E. N., Ispas, A.\& Dan, I. (2015). Assessing the Quality of Banking Services using the SERVQUAL Model. Romanian Journal of Marketing,2, 84-92.

Venter, R., Levy, A., Holtzhausen, M., Conradie, M., Bendeman, H. \& Dworzanowski-Venter, B. (2014). Labour Relations in South Africa, (5 $5^{\text {th }}$ Edition). Oxford University Press: Cape Town. 